\title{
Yield and Nutritional Quality Potential of Three Fodder Grasses in the Northern Region of Sri Lanka
}

\author{
M. Sarmini ${ }^{*}$ and S. Premaratne ${ }^{1}$ \\ Postgraduate Institute of Agriculture \\ University of Peradeniya \\ Sri Lanka
}

\begin{abstract}
Feeding standards of ruminant livestock could be significantly enhanced through the cultivation of improved quality forages which are suitable for different agroclimatic condition of the country. Therefore, a field experiment was carried out to assess the growth parameters, herbage yield and chemical composition of maize (Zea maize), sorghum (Sorghum bicolor (L.) moench), and hybrid Napier (Pennisetum perpureum X Pennisetum americarnum) in the northern region of Sri Lanka. The experiment was conducted during the period of December 2015 to June 2016 with three treatments consisted of maize (variety Pacific 984), sorghum (variety Sugargraze), and hybrid Napier (variety CO-3), each having three replicates under randomized complete block design. Growth parameters were measured at two week intervals up to the $8^{\text {th }}$ week and the crops were harvested at the $10^{\text {th }}$ week after planting for making silage. Among the species, maize was superior $(p<0.05)$ to others in terms of growth, and resulted the highest $(p<0.05)$ fresh matter yield of 52.27 t/ha/cut, with a dry matter yield of 17.11 t/ha/cut, whereas the lowest $(p<0.05)$ crude fiber and dry matter (DM) yield were obtained from CO-3. In terms of chemical composition, sorghum showed the highest $(p<0.05)$ crude protein $(C P)(14.37 \%)$ and in vitro dry matter digestibility $(\underline{I V D M D})(66.05 \%)$ while the lowest $(p<0.05) \underline{I V D M D}$ and $C P$ were recorded in CO-3 and maize, respectively on DM basis. In addition, the cost of production of maize and sorghum was less than that of $\mathrm{CO}-3$. The results revealed that maize and sorghum performed better than CO-3 in terms of growth, yield, nutrient composition, and cost effectiveness in the northern region of Sri Lanka.
\end{abstract}

Keywords: Chemical composition, forage yield, hybrid Napier variety CO-3, maize, sorghum

\section{INTRODUCTION}

Livestock production has been growing intensively in Sri Lanka aiming the achievement of the policy goal of production of sufficient animal protein with self-sufficiency in milk production. Development of livestock sector in Sri Lanka is hindered by many constrains, and unavailability of quality feed is a major factor (Houwers et al., 2015). The main feed resources for ruminants in Sri Lanka are natural pasture and crop residues, which are low in quality and quantity for sustainable livestock production (Ibrahim et al., 1999). This results in low productivity of dairy animals of the country (Premaratne and Premalal, 2006). Increased livestock production can be achieved through the cultivation of high-quality

\footnotetext{
1 Department of Animal Science, Faculty of Agriculture, University of Peradeniya, Sri Lanka

* Corresponding author: sarmini30@gmail.com
} 
forages with a high-yielding ability that is adapted to different agro-climatic condition of the country.

Northern Province is located in the dry zone of Sri Lanka which encompasses five administrative districts, namely Jaffna, Kilinochchi, Mullaitivu, Mannar, and Vavuniya. The area of Northern Province is $8,848.21 \mathrm{~km}^{2}$ accounting around $13.22 \%$ of the total land area of the island. The livestock industry is becoming an important part of agriculture in the Northern Province of Sri Lanka. The livestock sector is considered as a supplementary source of income for the farming society in the region. Average daily milk production of the Northern Province in 2014 was 65,663 liters (http://www.np.gov.lk, Accessed on 08.10.2016). The agro-climatic condition of the northern region is suitable for growing good quality tropical forages.

Many forage crops such as maize (Zea maize), sorghum (Sorghum bicolor (L.) moench), and hybrid Napier (Pennisetum perpureum X Pennisetum americarnum) variety CO-3 are grown by the farmers in the region. Maize is one of the most suitable crops having wide adaptability under varying agro-climatic conditions. As it has yielded a potential far higher than any other cereal crops, it is sometimes referred as the miracle crop or the 'Queen of Cereals'. Fodder quality of green maize is far undefined (Chaudhary et al., 2012). Sorghum is grown as an important forage crop in many parts of the world due to its profuse productivity and water use efficiency, especially under drought conditions (Sanchez et al., 2002). Fodder sorghum is stimulated at large-scale dairy farms of Sri Lanka, to bridge the dry season that lasts from October to January (Houwers et al., 2015). CO-3 was developed by the Tamil Nadu Agricultural University in Coimbatore, India and introduced to Sri Lanka in 1999. It is a popular fodder crop among farmers at present. CO-3 is characterized by its profuse tillering ability, high yield potential, high crude protein concentration, quick re-growth capacity, high palatability, free from other adverse factors and resistance to pest and disease attacks (Premaratne and Premalal, 2006).

Along with high yielding potential and climatic adaptability, nutritional quality is also a criterion for the selection of suitable fodder grasses by the farmers in the Northern Province of Sri Lanka. Therefore, a field experiment was conducted to evaluate the growth, yield, and nutritional quality of fodder maize (Zea maize) variety Pacific 984, sorghum (Sorghum bicolor (L.) moench) variety Sugargraze, and hybrid Napier (Pennisetum perpureum X Pennisetum americarnum) variety CO-3 in the northern region of Sri Lanka.

\section{METHODOLOGY}

A field experiment to compare the growth, forage yield, and nutritional quality of three fodder species was conducted from December 2015 to June 2016 at a farmer's field, located in the Thavasikulam village $\left(8.74158^{0} \mathrm{~N}\right.$ latitude, $80.47671{ }^{0} \mathrm{E}$ longitudes; 104 meters elevation), $5 \mathrm{~km}$ South West of Vavuniya city in Sri Lanka. The soil type in the area is Reddish Brown Earth (Mapa et al., 2010). Fodder sorghum variety Sugargraze, maize variety Pacific 984 and hybrid Napier variety CO-3 were chosen for the study. The experiment was laid out in a randomized complete block design (RCBD) having three replications. The plot size was $5 \times 5 \mathrm{~m}$. Three seeds of the maize and sorghum were planted in one spot manually at the spacing of $45 \times 30 \mathrm{~cm}$ and $65 \times 45 \mathrm{~cm}$, respectively. After germination, only two healthy plants were selected for further study from each spot. Stem cuttings of CO-3 having two healthy nodes were planted with 1 X $1 \mathrm{~m}$ spacing. 
Soil samples were collected randomly from the experimental plots before planting and analyzed for physicochemical properties $(\mathrm{pH}-7.2$, Electrical Conductivity $-1.1 \mathrm{mS} / \mathrm{m}$, organic matter $-0.88 \%$, total $\mathrm{N}-0.11 \%$, soil texture - sandy clay loam) using standard methods (Dharmakeerthi et al., 2007; Reeuwijk, 2002) to determine the application of organic and inorganic fertilizer. Before planting, farmyard manure at the rate of $15 \mathrm{t} / \mathrm{ha}$ (Premaratne and Premalal, 2006) was applied and the recommended fertilizer dose of 200: 120: $100 \mathrm{~kg}$ Urea: Triple super phosphate: muriate of potash $\mathrm{ha}^{-1}$ was applied as a basal application on the tenth day after planting. Plots were irrigated with an equal amount of water when required. Weeds were slashed after one month of establishment.

During the growing period, for each variety, five plants from each plot were randomly selected to measure the growth. Growth parameters such as the height of the plant from the base where it touches the soil to the vertically held leaf tip, number of leaves, and number of tillers were measured at two weeks interval up to the eighth week of growth. The crops were harvested at the proper stage of maturity level which was around 70 days after planting for making silage. Sub-samples $(600 \mathrm{~g})$ of each fodder species were taken, chopped, and dried in an oven at $60{ }^{\circ} \mathrm{C}$ until constant weight was obtained. Dried samples were ground to pass a 1 $\mathrm{mm}$ sieve and analyzed for proximate composition. Crude protein $(\mathrm{CP})$, crude fiber (CF), ether extract (EE), organic matter $(\mathrm{OM})$ and total ash were determined according to the AOAC (2005) procedure. In vitro dry matter digestibility (IVDMD) was determined according Tilley and Terry method (1963) as modified by VanSoest and Robertson (1985).

The collected data were statistically analyzed using Statistical Analysis Software version 9.1.3 (SAS, 2009), and Duncan's multiple range test (DMRT) was used to compare means.

\section{RESULTS AND DISCUSSION}

\section{Growth parameters}

The growth parameters such as number of leaves per plant, plant height, and leaf length of maize, sorghum, and CO-3 are shown in Tables 1 to 3 . The results indicated that the number of leaves, plant height and leaf length of all fodder species increased with maturity.

Table1. Number of leaves per plant (Mean \pm SE) of maize, sorghum and CO-3 at different stage of maturity ${ }^{\dagger}$

\begin{tabular}{lcccc}
\hline \multirow{2}{*}{ Species } & \multicolumn{4}{c}{ Number of leaves } \\
\cline { 2 - 5 } & Week 2 & Week 4 & Week 6 & Week 8 \\
\hline Maize (Pacific 984) & $5.93^{\mathrm{a}} \pm 0.12$ & $7.73^{\mathrm{a}} \pm 0.12$ & $9.53^{\mathrm{a}} \pm 0.26$ & $11.07^{\mathrm{a}} \pm 0.21$ \\
Sorghum (Sugargraze) & $5.40^{\mathrm{a}} \pm 0.19$ & $6.80^{\mathrm{a}} \pm 0.33$ & $8.27^{\mathrm{a}} \pm 0.21$ & $8.67^{\mathrm{a}} \pm 0.25$ \\
CO-3 & $5.27^{\mathrm{a}} \pm 0.33$ & $24.73^{\mathrm{b}} \pm 2.03$ & $44.33^{\mathrm{b}} \pm 3.90$ & $109.67^{\mathrm{b}} \pm 2.73$ \\
\hline
\end{tabular}

${ }^{\dagger}$ Means with different superscripts in columns are significantly different $(\mathrm{p}<0.05)$

Hybrid Napier variety CO-3 at $4^{\text {th }}, 6^{\text {th }}$ and $8^{\text {th }}$ week of growth stage produced the highest $(p<0.05)$ number of leaves compared to the other two fodders (Table 1) where, no significant differences were observed between sorghum and maize. This may be due to the profuse tillering capacity of CO-3 (Premaratne and Premalal, 2006) compared to the other two fodders. A field experiment of CO-3 carried out by Mounika et al. (2015) in India reported a high number of leaves $(156.15)$ per plant at $13^{\text {th }}$ week with 45 X $45 \mathrm{~cm}$ spacing. Since leaves 
have higher nutritive values than the stem of the plant, the number of leaves per plant is a very important parameter for calculating the growth and forage yield of fodder species (Ibrahim et al., 2014). Variation in results may be due to the differences in maturity level, plant spacing, and climatic conditions.

Table 2. Plant height (Mean $\pm \mathrm{SE}$ ) of maize, sorghum and CO-3 at different stage of maturity ${ }^{\dagger}$

\begin{tabular}{lcccc}
\hline \multirow{2}{*}{ Species } & \multicolumn{4}{c}{ Plant height (cm) } \\
\cline { 2 - 5 } & Week 2 & Week 4 & Week 6 & Week 8 \\
\hline Maize (Pacific 984) & $34.83^{\mathrm{b}} \pm 1.48$ & $76.53^{\mathrm{b}} \pm 2.20$ & $143.47^{\mathrm{b}} \pm 3.12$ & $213.33^{\mathrm{b}} \pm 2.68$ \\
Sorghum (Sugargraze) & $34.93^{\mathrm{b}} \pm 1.47$ & $76.33^{\mathrm{b}} \pm 2.81$ & $149.87^{\mathrm{b}} \pm 2.68$ & $231.67^{\mathrm{c}} \pm 3.42$ \\
CO-3 & $27.17^{\mathrm{a}} \pm 1.78$ & $62.20^{\mathrm{a}} \pm 2.06$ & $102.80^{\mathrm{a}} \pm 3.32$ & $145.80^{\mathrm{a}} \pm 2.64$ \\
\hline
\end{tabular}

${ }^{\dagger}$ Means with different superscripts in columns are significantly different $(\mathrm{p}<0.05)$

According to the Table 2, sorghum was the tallest at the $8^{\text {th }}$ week $(\mathrm{p}<0.05)$ growth, whereas the lowest plant height was observed in CO-3. Similar plant height of CO-3 $(144.19 \mathrm{~cm})$ was recorded by Mounika et al. (2015) whereas values reported by Wangchuk et al. (2015) for plant height $(175 \mathrm{~cm})$ and leaf number (360) grown in Bhutan after one year of establishment varied highly. According to Epasinghe et al. (2012), mean plant height for CO-3 $(172 \mathrm{~cm})$ was higher compared to maize $(199 \mathrm{~cm})$ and sorghum $(218 \mathrm{~cm})$ at $9^{\text {th }}$ week of growth when grown in the wet zone of Sri Lanka. The possible explanation for the variable results may be due to the diverse agro-climatic condition between the wet and dry zones of Sri Lanka.

Table 3. Leaf length (Mean $\pm \mathrm{SE}$ ) of maize, sorghum and CO-3 at different stage of maturity ${ }^{\dagger}$

\begin{tabular}{lcccc}
\hline \multirow{2}{*}{ Species } & \multicolumn{4}{c}{ Leaf length (cm) } \\
\cline { 2 - 5 } & Week 2 & Week 4 & Week 6 & Week 8 \\
\hline Maize (Pacific 984) & $32.33^{\mathrm{b}} \pm 1.12$ & $57.27^{\mathrm{a}} \pm 4.56$ & $88.47^{\mathrm{c}} \pm 1.64$ & $91.27^{\mathrm{a}} \pm 1.43$ \\
Sorghum (Sugargraze) & $26.63^{\mathrm{a}} \pm 1.45$ & $56.20^{\mathrm{a}} \pm 1.78$ & $79.67^{\mathrm{b}} \pm 1.67$ & $86.13^{\mathrm{a}} \pm 1.84$ \\
CO-3 & $49.27^{\mathrm{c}} \pm 1.81$ & $58.87^{\mathrm{a}} \pm 1.97$ & $70.53^{\mathrm{a}} \pm 2.18$ & $85.60^{\mathrm{a}} \pm 2.07$ \\
\hline
\end{tabular}

${ }^{\dagger}$ Means with different superscripts in columns are significantly different $(\mathrm{p}<0.05)$

The mean leaf length of forage species was not different $(p>0.05)$ at $4^{\text {th }}$ and $8^{\text {th }}$ week of growth stage where maize produced the highest leaf length (Table 3 ). In general, when the leaf length increases, leaf area of the plant will also increase and leads to a higher forage yield, attributing to efficient photosynthesis (Goldsworthy et al., 1974; Awan et al., 2001; Amin, 2011). A similar finding was observed in the present study. Leaf length of CO-3 measured at the $8^{\text {th }}$ week of maturity was similar to that of leaf length $(82.26 \mathrm{~cm})$ reported by Mounika et al. (2015) at $13^{\text {th }}$ week of growth.

\section{Fresh and dry matter yield of fodder}

The forage yield of the three fodder species is given in Table 4. According to the yield obtained at the $10^{\text {th }}$ week, fresh and dry matter yield were the highest $(p<0.05)$ in maize compared to the others. The dry matter yield of maize in the present study is comparable to the findings of Wiersma et al. (1993) who reported $15.30 \mathrm{t} / \mathrm{ha}$ at half milk line stage of hybrid maize in the North Central Wisconsin. However, Uzun et al. (2009) reported 76.48 
$\mathrm{t} /$ ha fresh matter yield of sorghum after $15^{\text {th }}$ week of planting in Turkey. The fresh matter yield reported for CO-3 in the present study was slightly higher than the values of 29.77 and $27.56 \mathrm{t} / \mathrm{ha} /$ cut reported by Chellamuthu et al. (2011) and Mounika et al. (2015), respectively, when cut at $13^{\text {th }}$ week after planting in India. A study conducted by Epasinghe et al. (2012) in the wet zone of Sri Lanka has recorded an average dry matter yield of 3.57, 3.66, 5.23 $\mathrm{t} /$ ha/cut for maize (Rambo), CO-3 and Sugargraze, respectively at $9^{\text {th }}$ week of planting. The variation in the yield may be due to the differences in the variety of maize, soil, climatic condition, and maturity level at harvest.

Table 4. Fresh and dry matter yield (Mean \pm SE) of maize, sorghum and CO-3 at $10^{\text {th }}$ week after planting ${ }^{\dagger}$

\begin{tabular}{lcc}
\hline Species & Fresh matter yield (t/ha) & Dry matter yield (t/ha) \\
\hline Maize (Pacific 984) & $52.27^{\mathrm{c}} \pm 1.16$ & $17.11^{\mathrm{b}} \pm 0.38$ \\
Sorghum (Sugargraze) & $40.27^{\mathrm{b}} \pm 0.15$ & $6.26^{\mathrm{a}} \pm 0.02$ \\
CO-3 & $36.00^{\mathrm{a}} \pm 0.23$ & $6.12^{\mathrm{a}} \pm 0.03$ \\
\hline
\end{tabular}

${ }^{\dagger}$ Means with different superscripts in columns are significantly different $(\mathrm{p}<0.05)$

Although high yield was reported in maize variety, multi harvests could be obtained from the other two fodder species used in the present study. CO-3 could be maintained as a perennial crop up to 2 years under proper management practices together with the correct application of fertilizer, irrigation in drought period (Premaratne and Premalal, 2006), whereas sorghum could be managed properly as a ratoon crop to get up to three harvests. However, the cost of maintenance will be high if the crop is harvested continuously. The cost of production of green forages were $1.75,2.09$, and $5.7 \mathrm{Rs} / \mathrm{kg}$, whereas the expenses for the production of dry fodder were 5.35, 13.44, and $32.66 \mathrm{Rs} / \mathrm{kg}$ for maize, sorghum, and CO-3, respectively. According to the results, the production cost of sorghum was twice of that of maize, whereas CO-3 showed five times high production cost compared to maize. This is due to the high production cost and low productivity of CO-3 compared to the other two fodder species.

\section{Chemical composition of fodder species}

The highest $(\mathrm{p}<0.05)$ values for $\mathrm{CP}$ and $\mathrm{CF}$ were observed in sorghum whereas, maize reported the lowest $(\mathrm{p}<0.05)$ amount of $\mathrm{CP}$ at the time of harvesting (Table 5). According to Epasinghe et al. (2012), the CP content of Sugargraze in the wet zone of Sri Lanka at the $7^{\text {th }}$ week of growth was $17.12 \%$, whereas a value of $12.2 \%$ was reported on $7^{\text {th }}$ week of growth in Indonesia by Moran (2005) indicating the location specific variations in composition.

Table 5. Chemical composition (Mean \pm SE) of maize, sorghum and CO-3 (g/100 g DM) ${ }^{\dagger}$

\begin{tabular}{lccc}
\hline Parameters & Maize (Pacific 984) & Sorghum (Sugargraze) & CO-3 \\
\hline DM & $32.73^{\mathrm{c}} \pm 0.01$ & $15.55^{\mathrm{a}} \pm 0.02$ & $17.00^{\mathrm{b}} \pm 0.01$ \\
CP & $7.35^{\mathrm{a}} \pm 0.09$ & $14.37^{\mathrm{c}} \pm 0.01$ & $10.92^{\mathrm{b}} \pm 0.17$ \\
CF & $35.15^{\mathrm{a}} \pm 0.60$ & $38.28^{\mathrm{b}} \pm 0.14$ & $33.35^{\mathrm{a}} \pm 0.57$ \\
EE & $2.45^{\mathrm{a}} \pm 0.01$ & $3.74^{\mathrm{b}} \pm 0.05$ & $4.34^{\mathrm{c}} \pm 0.05$ \\
ASH & $10.70^{\mathrm{a}} \pm 0.18$ & $11.76^{\mathrm{b}} \pm 0.02$ & $16.06^{\mathrm{c}} \pm 0.01$ \\
OM & $78.59^{\mathrm{c}} \pm 0.36$ & $76.49^{\mathrm{b}} \pm 0.41$ & $67.87^{\mathrm{a}} \pm 0.01$ \\
\hline
\end{tabular}

${ }^{\dagger}$ Means with different superscripts in rows are significantly different $(\mathrm{p}<0.05)$ 
Chaudhary et al. (2012) reported a value of 7\% CP for maize at milky stage in an experiment done in India, whereas a value of $16.33 \%$ was reported by Epasinghe et al. (2012) at $7^{\text {th }}$ week of growth in the wet zone of Sri Lanka. The low CP content obtained in the present study might be due to the difference in maturity level, and variety. However, the CP content of CO-3 in the present study was in accordance with the findings of Vijayakumar et al. (2009) and Wangchuk et al. (2015). In contrast, Premaratne and Premalal (2006) reported a CP content of $15-16 \%$ for CO-3 when harvested at the proper stage of maturity in the mid country of Sri Lanka. According to the Table 5, DM content of maize was twice of that of sorghum and CO-3, whereas the EE and ash contents of CO-3 reported the highest $(p<0.05)$ value compared to other two species. The CP, CF, EE, and ash content reported by Heuze et al. (2015) were 3.0-12.8, 19.1-36.6, 0.7-3.1, and 2.5-11.8\%, respectively for maize and 2.5$16.3,22.6-43.2,1.1-3.1$, and $5.4-13.7 \%$, respectively for sorghum. The values obtained in the present study were in accordance with the report of Heuze et al. (2015). Crude fiber and ash content of CO-3 reported by Premaratne and Premalal (2006) and Epasinghe et al. (2012) deviate slightly from the present observations. These deviations could attribute to the difference in soil and climatic condition of two zones, namely wet and dry zone of Sri Lanka.

The IVDMD values among forages were $60.84,66.05$, and $55.95 \%$, respectively for maize, sorghum and CO-3. Sorghum showed the highest $(\mathrm{p}<0.05)$ IVDMD while CO-3 recorded the lowest $(\mathrm{p}<0.05) I V D M D$. The IVDMD values observed from the three fodder crops were comparable to the finding of Epasinghe et al. (2012). The feeding value of forage is determined primarily by the intake and digestibility. Digestibility is variable among various fodder sources and is an inverse function of lignifications (Ouda et al., 2005).

\section{CONCLUSIONS}

Maize, variety Pacific 984 produced the highest fresh and dry matter yield compared to sorghum, variety Sugargraze and hybrid Napier, variety CO-3 within the $10^{\text {th }}$ week of growth. Sugargraze was superior to Pacific 984 and CO-3 in terms of crude protein and in vitro dry matter digestibility. Based on the results obtained from the nutritional quality, forage yield, and cost of production, Pacific 984 and Sugargraze performed well compared to $\mathrm{CO}-3$ in the field located in the northern region of Sri Lanka.

\section{ACKNOWLEDGEMENTS}

The authors acknowledge the University Grants Commission for the financial assistance, and Dr. Mrs. S Kalpana, Veterinary Investigation Officer, Veterinary Investigation Center, Vavuniya for the land and other facilities provided to conduct the field experiments.

\section{REFERENCES}

Amin, M.E.M.H. (2011). Effect of different nitrogen sources on growth, yield, and quality of fodder maize (Zea mays L). J. Saudi Society of Agric. Sci. 1, 17 - 23.

AOAC. (2005). Official Methods of Analysis of AOAC International, 18th Ed: Association of Official Analytical Chemists, Maryland, USA. 
Awan, T.H., Mahmood, M.T., Maqsood, M., Usman, M. and Hussain, M.I. (2001). Studies on hybrid and synthetic cultivars of maize for forage yield and quality. Pak. J. Agric. Sci. 38, $1-2$.

Chaudhary, D.P., Kumar, A. Mandhania, S.S., Srivastava, P. and Kumar, R.S. (2012). Maize as fodder? An alternative approach, Directorate of Maize Research, Pusa Campus, New Delhi -110 012, Technical Bulletin. 04, 32. [on line] [Accessed on 20.04.2016]. Available at http://www.iimr.res.in/download/Maize\%20as\%20Fodder.pdf.

Chellamuthu, V., Saravanane, P. and Paradise, S.G. (2011). Evaluation of Bajra-Napier hybrid grass cultivars under coastal ecosystems of Karaikal, Puducherry Union Territory. Madras Agric. J. 98, 253 - 254.

Dharmakeerthi, R.S., Indraratne, S.P. and Kumaragamage, D. (2007). Manual of Soil sampling and analysis. Soil Science Society of Sri Lanka, Peradeniya, Sri Lanka.

Epasinghe, M., Jayawardena, V.P. and Premalal, G.G.C. (2012). Comparison of growth, yield and nutritive value of maize, multi-cut fodder sorghum and hybrid Napier (var. CO-3) grown in wet zone of Sri Lanka. Proceedings of $22^{\text {nd }}$ annual students research session (Editors: Suranga P.Kodithuwakku and S. M. C. Himali). Department of Animal Science, Faculty of Agriculture, University of Peradeniya, Sri Lanka. 23-25.

Goldsworthy, P.R., Palmer, A.F.E. and Sperling, D.W. (1974). Growth and yield of lowland and tropical maize in Mexico. J. Agric. Sci. Camb. 83, 223 - 230.

Heuze, V., Tran, G., Edouard, N. and Lebas, F. (2015). Maize green forage. Feedipedia, a programme by INRA, CIRAD, AFZ and FAO. [on line] [Accessed on 09.10.2016]. Available at http://www.feedipedia.org/node/358.

Houwers, W., Wouters, B. and Vernooij, A. (2015). Sri Lanka fodder study; an overview of potential, bottlenecks and improvements to meet the rising demand for quality fodder in Sri Lanka. Lelystad, Wageningen UR (University \& Research center) Livestock Research, Livestock Research Report. 924.

Ibrahim, M., Maqbool, M.M., Ayub, M., Ahmad, M.I., Tahir, I., Nadeem, M.S., UlHaq, T. and Nadeem, M.M. (2014). Evaluating the forage yield and quality potential of different maize cultivars under different harvesting times. Int. J. Modern Agric. 3, 1 - 6.

Ibrahim, M.N.M., Staal, S.J., Daniel, S.L.A. and Thorpe, W. (1999). Appraisal of the Sri Lanka dairy sector. Volume 1, Main Report. Ministry of Livestock Development and Estate Infrastructure, Sri Lanka. 97.

Mapa, R.B., Somasiri, S. and Dassanayaka, A.R. (2010). Soils of the Dry Zone of Sri Lankamorphology, characterization and classification. Survodaya Vishva Lekha, Sri Lanka.

Moran, J. (2005). Tropical dairy farming: feeding management for small holder dairy farmers in the humid tropics. Land links press. 312. [on line] [Accessed on 12.03.2016]. Available at http://www.publish.csiro.au/act=view_file\&file_id=SA0501001.pdf.

Mounika, B., Chellamuthu, V. and Sridevi, V. (2015). Plant spacing influence on the relative productivity of Bajra Napier hybrid grasses. Int. J. Trop. Agric. 33, 875 - 878. 
Ouda, J.O., Njehia, G.K., Moss, A.R., Omed, H.M., Nsahlai, I.V. (2005). The nutritive value of forage sorghum genotypes developed for the dry tropical highlands of Kenya as feed source for ruminants. South Afr. J. Anim. Sci., 35(1), 55 - 60.

Premaratne, S. and Premalal, G.G.C. (2006). Hybrid Napier (Pennisetum perpureum $x$ Pennisetum americarnum) Var. CO-3: A resourceful fodder grass for dairy development in Sri Lanka. J. Agric. Sci. 2, 22 - 33.

Reeuwijk, V.L.P. (2002). Procedures for soil analysis. Technical Paper n. 9. International Soil Reference and Information Centre, Wageningen, The Netherlands.1-14

Sanchez, A.C., Subudhi, P.K., Rosenow, D.T. and Nguyen, H.T. 2002. Mapping QTLs associated with drought resistance in sorghum (Sorghum bicolor L. Moench). Plant. Mol. Biol. 48, 713 - 726.

SAS. (2009). SAS/STAT User's Guide. Version 6.12, SAS Institute Inc., Cary, North Carolina, USA.

Statistical information of the Northern Province. (2015) [on line] [Accessed on 08.10.2016]. Available at http://www.np.gov.lk.

Tilley, J.M.A. and Terry, R.A. (1963). A two stage technique for In Vitro digestion of forage crops. Journal of British Grassland Society.18, 104 - 111.

Uzun, F., Ugur, S. and Sulak, M. (2009). Yield, nutritional and chemical properties of some Sorghum x Sudan grass hybrids (Sorghum bicolour (L.) Moench x Sorghum sudanense Stapf.). J. Anim. and Vet. Adv. 8, 1602 - 1608.

VanSoest, P.J. and Robertson, J.B. (1985). Analysis of Forage and Fibrous Foods. A laboratory manual for Animal Science. 613, Carnell University, Ithaca, New York, USA.

Vijayakumar, G., Babu, C., Velayudham, K. and Raveendran, T.S. (2009). A high yielding Cumbu Napier hybrid grass CO (CN) 4. Madras Agric. J. 96, 291 - 292.

Wangchuk, K., Rai, K., Nirola, H., Thukten, Dendup, C. and Mongar, D. (2015). Forage growth, yield, and quality responses of Napier hybrid grass cultivars to three cutting intervals in the Himalayan foothills. Trop. Grasslands. 3, 142 - 150.

Wiersma, D.W., Carter, P.R., Albrecht, K.A. and Coors, J.C. (1993). Kernel milk line stage and maize forage yield, quality, and dry matter content. J. Production Agric. 6, 94 - 99. 